The Modern Idea

of History and its Value 



\section{The Modern Idea of History and its Value}

An Introduction by

Chiel van den Akker 
Original title Geschiedenis

First published in 2019 by Athenaeum - Polak \& Van Gennep, Amsterdam

Copyright (C) 2019 by Chiel van den Akker

Chapter 6: (C) C. van den Akker / Amsterdam University Press B.V., Amsterdam 2020

Cover illustration: Nicolas Poussin, A Dance to the Music of Time, c. 1634-1636. Via Wikimedia Commons. () Public Domain

Cover design:

Lay-out: Crius Group, Hulshout

ISBN $\quad 9789463728331$

e-ISBN $\quad 9789048552054$

NUR $\quad 687$

(C) C. van den Akker / Amsterdam University Press B.V., Amsterdam 2020

All rights reserved. Without limiting the rights under copyright reserved above, no part of this book may be reproduced, stored in or introduced into a retrieval system, or transmitted, in any form or by any means (electronic, mechanical, photocopying, recording or otherwise) without the written permission of both the copyright owner and the author of the book.

Every effort has been made to obtain permission to use all copyrighted illustrations reproduced in this book. Nonetheless, whosoever believes to have rights to this material is advised to contact the publisher. 


\section{Table of Contents}

Preface

Acknowledgements

1. The Value of History for Life

2. The First Historian

3. Historicism

4. Reasons and Causes

5. Historical Insight

6. Narration

7. The Historical Sublime

131

8. Epilogue

151

Sources and Notes

List of Illustrations

163

Recommended Readings

Index 



\section{Preface}

This short book aims to answer two questions: What is history? And what is its value? It also attempts to show how the answers to these questions are mutually dependent. Think for instance of the old view that history is the teacher of life. This view assumes that the past is a reservoir of examples from which moral lessons for the present can be drawn. If one attempts to theorize what history is, one immediately moves on to speculating what history is for.

I am not the first to ask these questions. This book discusses the answers of a select group of influential historians and philosophers. These individuals were chosen for their inspiring and influential views on history and its value. I will set them in conversation with one another and show how their views are still relevant today.

Mostly, I will focus on the modern idea of history and its criticism. The ancient Greeks' conception of history is, however, an indispensable part of both. The modern idea of history is the product of the nineteenth century, when history solidified as an academic discipline and philosophers posited the idea that the course of history is intelligible.

I hope this short book will stimulate readers to think about their idea of history and its usefulness. I also hope that they will look with fresh eyes at the histories that are told today. This book is meant for anyone with an interest in the concept of history and its value, and it is especially intended for students of history.

At the end of this book, the reader will find an overview of the sources on which each chapter draws and an index. I also 
provide a list of recommended - mostly recent - readings for those who want to look further into the subjects this book touches upon. 


\section{Acknowledgements}

This book is a revised edition and translation of my Dutch book Geschiedenis in the series Elementaire Deeltjes, which was published by Athenaeum in Amsterdam in 2019. Chapter 6 is newly written for this book. I am very grateful to Daniel Woolf for correcting the English of my manuscript and for his many helpful suggestions.

Chapter 2 quotes from Thucydides, OnJustice, Power, and Human Nature. The Essence of Thucydides' History of the Peloponnesian War, edited and translated by Paul Woodruff, (C) Hackett Publishing 1993. These quotes are reprinted by permission of Hackett Publishing Company, Inc. All rights reserved. The same publisher also gave permission to use quotes from Nietzsche's On the Advantage and Disadvantage of History for Life, which was translated by Peter Preuss and published in 1980. 



\section{The Value of History for Life}

The title of this first chapter refers to the 1874 essay Vom Nutzen und Nachteil der Historie für das Leben by the German philologist Friedrich Nietzsche (1844-1900). History, Nietzsche claimed, is to serve life. This was not a new claim; to the contrary. Nietzsche himself points to the Greek historian Polybius (c. 200-120), whose work on the Roman Empire starts with the comment that there is no better guide to life than knowledge of the past. He says:

Polybius, for example, calls political history the proper preparation for governing a state and the great teacher who, by reminding us of the sudden misfortunes of others, exhorts us steadfastly to bear the reverses of fortune. (p. 15)

In his essay, Nietzsche is not interested in political history. He is also not solely concerned with 'men of action', as was Polybius, who wrote his history with the politicians and military leadership of the Roman Empire in mind. But everyone benefits from history according to Polybius, as Nietzsche emphasizes, for history teaches us how to bear the vicissitudes of fortune.

The idea that history is the teacher of life is an old one. It is typical of the so-called exemplary history which was dominant from Roman antiquity to the nineteenth century. The past offered exempla ('examples') of behaviour from which political and moral lessons could be drawn. Think for instance of the following advice offered by Polybius:

It is of the greatest importance for statesmen to make sure that they understand the true reasons whereby old enmities are 
reconciled or new friendships formed. They should observe when it is that men come to terms because they are yielding to circumstances, and when because their spirit has been broken. (III.11)

Given the examples it could provide, the past also served a function in speeches: An orator could use examples from the past to give authority and credibility to his arguments - and to entertain his audience, as the Roman politician and orator Marcus Tullius Cicero (106-143) added. For a historian such as Polybius, such a rhetorical use of history was far removed from the kind of work he did as a historian. But for him, too, history had a didactic function. It was political and moral instruction: Philosophy teaching by example, and as such was a guide to life.

While others in the nineteenth century would reject exemplary history (a point we will come back to later), Nietzsche gives it his own twist. He also emphasizes that while history can be useful, it may also be an obstacle to life. He warns us of having too much history. An excess of history was, Nietzsche believed, a problem in the nineteenth century. Never before had there been so much knowledge of the past available. Man had to carry an evergrowing past along with him.

The answer to what history is provides an answer to what its use is and vice versa. This is evident in the old view that history is political and moral instruction using past examples. When preparing for a political career, it is good to know how to conclude treaties and wage wars, and what personality traits are required for these activities. It is also good to have knowledge of the various forms of government, and how they are subject to change. The 
interdependence between the two questions is nowhere as clear as in Nietzsche's essay. That is why this book starts with him.

In his essay, Nietzsche distinguishes between three kinds of history: the monumental, the antiquarian, and the critical. They are respectively concerned with the person who acts and strives for something, the person who wants to preserve and venerate the past, and the person who suffers and seeks liberation from it. Each kind of history may serve life and is useful in its own right. A balance must therefore be struck between these kinds of history. Nietzsche puts it thus:

If the man who wants to achieve something great needs the past at all he will master it through monumental history; who on the other hand likes to persist in the traditional and venerable will care for the past as an antiquarian historian; and only he who is oppressed by some present misery and wants to throw off the burden at all cost has a need for critical, that is judging and condemning history. (pp. 18-19)

With these distinctions, Nietzsche reverts to older kinds of history that had fallen into disuse in the nineteenth century among academically trained historians and other scholars. He does, however, offer his own interpretation of the terms he uses, thereby giving them a broader meaning.

The antiquarian historical sense is for people who cherish traditions. Such people feel connected to their environment and the customs that are common there. They value an heirloom because it is part of their family history. A parent's diary is retained because they recognize themselves in the 
life it describes. The simple rural life is appreciated because that life has been lived there for centuries. Walking down a city street evokes the feeling of kinship with previous residents. And when they hear the national anthem being played, they feel connected to their fatherland. Nietzsche writes:

This antiquarian historical sense of reverence is of highest value where it imbues modest, coarse, even wretched conditions in which a man or a people live with a simple touching feeling of pleasure and contentment. (pp. 19-20)

Antiquarian history shows that the life we're living is not accidental and random: It has grown that way historically. Feeling connected with the past - with our heritage - and cherishing that connection reassures us. This is how antiquarian history serves life.

The antiquarian historical sense is not without its dangers. The danger is that everything that is old is perceived as equally venerable, simply because it is old, and all the new is rejected, because it cannot be better than the old. Life is only preserved, even mummified, in antiquarian history. The past continuously offers itself for comparison, giving us the feeling that we are but descendants and epigones, and that the present has nothing to offer. At such a moment, the past has become a burden:

Then you may well witness the repugnant spectacle of a blind lust for collecting, of a restless raking together of all that once has been. (p. 21)

The antiquarian historical sense acquires a systematic meaning in Nietzsche's essay. The desire to hold on to the 
past by preserving it, and the veneration of what is old, are phenomena of all times and places. ${ }^{1}$

Nietzsche concludes that the antiquarian historical sense cannot generate life. It can only preserve it. That is why we need the two other kinds of history.

Sometimes we have to be critical of the past and condemn it. Such is the case when the past is experienced as a burden and we wonder how we can organize life in such a way that we are freed from that burden. This is how the critical sense of history serves life. For this critical sense, a person

must have the strength, and use it from time to time, to shatter and dissolve something to enable him to live: this he achieves by dragging it to the bar of judgment, interrogating it meticulously and finally condemning it. (pp. 21-22)

Here, Nietzsche is concerned with human errors and forms of injustice that deserve to be banished. He gives as an example the privileges possessed by some historical groups and points to the systems of castes and dynasties. Today, we would include in this consideration such historical phenomena as slavery, colonialism, the inequality between men and women, and racism.

1 It should be noted that antiquarianism has an additional historical meaning, though not one that interested Nietzsche. It has commonly been used to describe the activities of early modern collectors of plants, minerals, books, medals, coins, ancient manuscripts, and scientific instruments, and their preference for the curious, obscure, and particular. The antiquarian was often contrasted with the historian: The antiquarian collects, makes inventories, and systematizes his findings, but he does not select, as the historian does. Nor does the antiquarian, unlike the historian, use a chronological framework to interpret his objects. 
But critical history, too, is not without its dangers, as Nietzsche points out:

If we condemn those aberrations and think ourselves quite exempt from them, the fact that we are descended from them is not eliminated. (p. 22)

The temptation is strong to appropriate, in retrospect, a past from which we want to descend, instead of accepting the past from which we actually descended. No matter how often we condemn slavery and colonialism or reject racism and gender inequality, they remain part of the history that made us into who we are.

Thirdly, in addition to the antiquarian and critical kinds of history, Nietzsche discusses monumental history. This is the variety of history which reminds us that great things were possible in the past and that what was once done remains possible both now and in the future. This is how the monumental historical sense serves life. Nietzsche writes that this kind of history is for people who need models and teachers that they cannot find among their contemporaries. It gives strength to the person who wants to accomplish something great:

And yet time and again some awaken who, in viewing past greatness and strengthened by their vision, rejoice as though human life were a grand affair and as though it were even the sweetest fruit of this bitter growth to know that at some earlier time someone went through existence proud and strong, another in profound thought, a third helpfully and with pity. (pp.15-16)

The monumental kind of history points us to an inspirational past. It has this in common with the old exemplary 
history discussed earlier. We must indulge ourselves in Plutarch (c. 46-120), Nietzsche writes, in order that we believe in ourselves by believing in his heroes. (The Greek historian Plutarch is known for his dramatized biographies of distinguished Greeks and Romans in which he harmonizes different character types and their behaviours.)

Once again, however, this kind of history is not without its dangers. The first of these is that the specific circumstances of the great achievements in the past and their specific consequences are forgotten. A second is that the past in a monumental history may be represented more ideally than it actually was, risking transforming it from history into mere fiction. A third danger is that those parts of the past that were not great are neglected or forgotten. Finally, the analogies between the past and the present that the monumental historical sense suggests can be misleading. These analogies encourage overconfidence and fanaticism, and can lead to a misguided heroism in the present. In short, monumental history easily results in a glorification of the past for which the past itself provides no justification. The Dutch Golden Age is undoubtedly a high point in history. But that is no reason for that period to be glorified and presented more ideally than it in fact was. Its dark sides were numerous.

Nietzsche's distinction between the antiquarian, monumental, and critical kinds of history remains of use today, over a century after his death. It enables us to subdivide history into various categories and identify the pros and cons of each. History is of use to people who want to preserve and admire the past, to those who act and strive for something, and to those who suffer and seek liberation from a past that haunts them. 
Nietzsche also uses the distinction between the different kinds of history to determine how historians and other scholars should study the past. We will now turn our attention to this.

At first glance, one would think that the critical historical sense is most suited to describe the work of Nietzsche himself. He saw his task as a philologist to be critical of the modern age in which he lived. History had, during the nineteenth century, become an academic discipline, and people were inclined to regard life as thoroughly historical. Everything was becoming and also had a history. Later in his essay, however, it becomes clear that Nietzsche prefers the monumental historical sense (this is also apparent from his work on the first Greek philosophers, which he finished in 1873 , a year before his Vom Nutzen und Nachteil). He states that this kind of history focuses on the best specimens of man (I noted above that monumental history is reminiscent of exemplary history). In such specimens, even the purpose of humanity as a whole is to be found! They provide us with the strength and inspiration to do great things in our own time. It is therefore the task of historical studies to establish a conversation between geniuses. Nietzsche says the following about this:

These [geniuses] do not, as it were, continue a process but live in timeless simultaneity, thanks to history, which permits such co-operation, they live as the republic of geniuses of which Schopenhauer speaks somewhere. (p. 53)

Elsewhere in his essay, but in this context, he refers to Barthold Georg Niebuhr (1776-1831), the first history 
professor at the modern University of Berlin, founded in 1810. History, Niebuhr said, when

clearly and explicitly comprehended, has at least this one use: that one knows how even the greatest and highest spirits of humanity do not know how accidentally their vision adopted the form through which they see and through which they vehemently insist that everyone else see; vehemently that is, since the intensity of their consciousness is exceptionally great. (p. 12)

A great and exalted mind has us look at the world differently. This is what makes his work useful for life. Nietzsche would emphasize that the work of a genius is not merely a product of its time; we should not reduce such a work to its time by taking it to be simply the result of certain circumstances or developments. What is great is immortal, eternal, and therefore superhistorical.

Elsewhere in his essay, Nietzsche criticizes the usual working method of the academic historian: Instead of providing insight into the timelessness of the work of a genius, the historian places that work in a broader context; or he compares it with other, earlier works; or he diverts attention from the work itself by focusing on the influences or circumstances that made it possible; or he analyses it in such a way that it disintegrates into its analysed parts, as a result of which the wholeness of the work, and therefore the work itself, is lost. These are real dangers, which 21st century technology has magnified. Think of art historians who use modern techniques to look through the layers of paint in a painting and believe that what they find there is just as interesting as the painting itself. Or think of scholars who use digital techniques to analyse Shakespeare's corpus without ever 
reading an actual sonnet or attending a performance of one of his plays. In both cases, the research ignores the genius of the work, which can only be found in the way it changes our view of the world.

It should be noted that when Nietzsche points to the highest specimens of man he is not primarily thinking of politicians and military strategists, as was customary in exemplary history. To the contrary, he has in mind poets, artists, historians, and philosophers, men such as Goethe, Raphael, Thucydides, and Herakleitos. Or, to stay with our earlier example of the Dutch Golden Age, the likes of Vondel, Rembrandt, De Groot, and Spinoza, whose genius is what made that era both great and inspiring.

Nietzsche thus raises the suspicion of advocating a kind of alternative 'great man theory of history': One populated not by generals and politicians, but by scholars and artists. (The idea that all history is political history and concerned with politicians, their personalities, the decisions they made, and the elites to which they belonged, would itself become less and less self-evident in the course of the 2oth century). His call to the historian to constitute a republic of geniuses offers a model for intellectual history. Yet, as we will see, Nietzsche does not exclusively advocate for this history of great minds and their creations.

A central criticism in Nietzsche's essay is that the question of how history serves life falls outside the scope of the positivist, who wants to turn history into a science. The term 'positivism' stems from Auguste Comte (1798-1857), who intended by it the scientific approach of social reality. In the context of history as an academic discipline, positivism means two things. The positivist either merely sticks to the facts ('doing justice to the facts' is, according to Nietzsche, 
a typical German expression). Or he wants to transform history into social science, in line with the model offered by the natural sciences, and to discover the general laws that govern societies. The latter is what Comte had in mind. But, according to Nietzsche, historical studies should not look for general laws of human behaviour. At their best, these show how uniform and dependent the masses are, while what is interesting always rises above the masses. He writes:

I hope that history may not see its significance in general thoughts as a kind of bloom and fruit: rather that its value is just this, to describe with insight a known, perhaps common theme, an everyday melody, to elevate it, raise to a comprehensive symbol and so let a whole world of depth of meaning, power and beauty be guessed in it. (p. 36)

Nietzsche not only makes this remark in the context of criticizing the idea of turning historical studies into a social science modelled on the natural sciences but also underlines his preference for the monumental conception of history and the importance of the personality of the historian.

If you have not had some higher and greater experiences than all others you will not know how to interpret anything great and high in the past. (p. 38)

Only the great achievements of the past are worth knowing and preserving. The historian must be trained in such a way that he understands that. Once again, it becomes clear that the question of what history is - the description of everyday themes from the past and their depths of meaning, power, and beauty - can be directly linked to the question of its usefulness: History inspires us and provides insight that 
makes us look at reality in a different way. The answer to one question leads directly to an answer to the other.

In his essay, Nietzsche turns against his own time and calls his essay untimely. The need for history was strong in the nineteenth century, too strong according to Nietzsche. The French politician and historian Prosper de Barante (1782-1866) had even spoken of a historical fever in his 1828 essay 'De l'Histoire'. Nietzsche made the same diagnosis later that century but would, in contrast to Barante, regard it as dangerous and propose three remedies for this illness.

One remedy for an excess of history is simply to forget. Forgetting allows one to feel unhistorical and to hold on to the present moment instead of seeing a world that is merely in a state of becoming. However, forgetting everything is not an option; then we would also forget everything that makes us human. A past that keeps on forcing itself upon us as comparison and therefore is a burden is best condemned - this is the second remedy that Nietzsche offers. His third solution is to focus on the superhistorical: on the eternal that transcends the temporal, on the unchanging, instead of on that which is becoming in time. And then Nietzsche, like his friend the historian Jacob Burckhardt (1818-1897), thinks of art and religion, which give existence an unchanging and eternal character, the work of geniuses, and the power, wisdom, and beauty of everyday life. This third remedy leads to the monumental sense of history preferred by Nietzsche. What is beautiful, wise, powerful, and the product of genius does not belong to a certain time - it is not the product of it - but must be elevated above it. Only what is great in the past is worth knowing and preserving.

Because Nietzsche turns against his own time, he in effect returns to earlier, pre-modern views of history. The claim 
that only what was great in the past is worth preserving and knowing is one such view. The first historians in antiquity were already of that opinion, which we will discuss further in the next chapter. This theme also resonated at the beginning of the nineteenth century for the aforementioned Niebuhr (incidentally, one of the two nineteenth-century historians mentioned by name by Nietzsche, and the only one quoted with approval). In his history of Rome, Niebuhr had said that he would exclude from what the Romans themselves had written down that which was not great in itself and was without important consequences.

To the extent that this conception of greatness is reminiscent of the exemplary theory of history, it would have been rejected by Niebuhr and other historians of the early nineteenth century. They were particularly interested in the effects that actions and events would have in later times: Those effects were what revealed their greatness. However, nearer the end of the century, Nietzsche would, in his own way, argue for the monumental historical sense, which involves the things that are great in themselves, and not the processes and developments to which they contribute, nor their important consequences.

Nietzsche also discusses themes to which later authors would return, sometimes as a result of his work. The question whether history is or should be a science is one such theme. This theme will be discussed several times throughout this book. In line with this, Nietzsche's essay raises the question whether the subjectivity of the historian - his personality and presence in his work - is something positive. Shouldn't the historian be objective and erase his (subjective) personality from his work as much as possible? Chapter 5 deals with this issue. In this short book, I will point out Nietzsche's influence on later scholars a number of times. 
Nietzsche called his reflection on the value and dangers of history for life untimely. He does admit that he is a child of his time, but he is, above all, he says, a student of the ancient Greeks, with whom he felt a close bond. In particular, Nietzsche related most closely to the historian Thucydides (c. 460-40o), because of the genuine realism that characterizes the latter's work. In Nietzsche's mind, it is the work of a genius. Nietzsche's admiration for Thucydides was in this instance not 'untimely', at least not among historians. In the nineteenth century, the Greek's history of the Peloponnesian War served as a model for history-writing as it developed into an autonomous academic discipline. It was commonly held that anyone who wanted to know what history is should begin with Thucydides, the verissimo historiae parenti: the true father of history, as the lawyer Jean Bodin (1530-1596) had written as far back as the sixteenth century. The next chapter will argue that both Bodin and Nietzsche were right. 